\title{
Bone wax as a cause of a foreign body granuloma in a resternotomy: a case report
}

\author{
G Ozerdem*, M Hidiroglu², A Kucuker², A Kunt ${ }^{3}$, L Cetin² \\ From 23rd World Congress of the World Society of Cardio-Thoracic Surgeons \\ Split, Croatia. 12-15 September 2013
}

\section{Background}

Bone wax (beeswax) has been used to stop bleeding from the sternal cancellous bone after median sternotomy for many years. Bone wax may sometimes cause complications and surgeons should be aware of this possibility.

\section{Methods}

63 years old woman who had a previous cardiac surgery with median sternotomy was admitted for elective coronary artery bypass surgery. After re-sternotomy, different sized solid masses attached to the sternum and lying on the mediatinal structures consisting of bone wax surrounded by soft granulation tissue was seen. This material extended into the anterior mediastinum. The remnants of bone wax, surrounding inflammatory tissue and adjacent sternal callus were removed. The sternal edges were found to be separated by a cavity containing granular porridge material. The inflammatory tissue was removed together with some of the underlying bone. After performing coronary bypass surgery, the sternotomy was laid open throughout its length and the inflammatory material was scraped out to obtain bleeding bone. No wax was used during this procedure.

\section{Results}

The mass was excised and the postoperative follow up was uneventfull. Histopathologic examination showed foreign-body granulomatous reaction consisting of multinucleated giant cells surrounding wax particles interspersed with abundant mononuclear cells. Bone wax showed a marked foreignbody reaction and lack of bone reformation.

* Correspondence: asliastan@yahoo.com

${ }^{1}$ Kayseri Sevgi Hospital, Cardiovascular Surgery Department, Kayseri, Turkey Full list of author information is available at the end of the article

\section{Conclusion}

We report a case in which foreign-body reaction to bone wax applied over open heart surgery required reoperation. Bone wax controls bone bleeding mechanically by occluding the bleeding channels and tamponading the spaces in bone without any biochemical action. The properties and application of bone wax and their possible complications are discussed.

\section{Authors' details}

${ }^{1}$ Kayseri Sevgi Hospital, Cardiovascular Surgery Department, Kayseri, Turkey. ${ }^{2}$ Ataturk Training and Education Hospital, Ankara, Turkey. ${ }^{3}$ Konya Training and Education Hospital, Konya, Turkey.

Published: 11 September 2013

doi:10.1186/1749-8090-8-S1-P121

Cite this article as: Ozerdem et al.: Bone wax as a cause of a foreign body granuloma in a resternotomy: a case report. Journal of Cardiothoracic Surgery 2013 8(Suppl 1):P121.
Submit your next manuscript to BioMed Central and take full advantage of:

- Convenient online submission

- Thorough peer review

- No space constraints or color figure charges

- Immediate publication on acceptance

- Inclusion in PubMed, CAS, Scopus and Google Scholar

- Research which is freely available for redistribution
() Biomed Central

\section{() Biomed Central}

